\title{
A study on the occlusal wear patterns in maxillary posterior teeth with palatal side abfractions
}

\author{
Joo-Hun Song, Hee-Jung Kim, Gyeong-Je Lee* \\ Department of Prosthodontics, College of Dentistry, Chosun University, Gwangju, Republic of Korea
}

\begin{abstract}
Purpose: Aims to analyze the occlusal wear patterns in maxillary posterior teeth with palatal side abfractions and study the association between occlusal force and abfractions. Materials and Methods: This study was conducted in a total of 308 teeth from 148 patients with palatal side abfractions in maxillary posterior teeth. The occlusal wears in maxillary premolars and molars with palatal side abfractions were classified and recorded. The classification was done by type of teeth, age, and gender, and in order to evaluate the statistical significance between groups, chi-square test was conducted ( $\alpha=0.05$ ). Results: Palatal side abfractions in maxillary posterior teeth were observed at the highest frequency in the 1st molars, and in all teeth with palatal side abfractions, more than one occlusal wear was observed. In classification by type of teeth, by age, and by gender, the occlusal wears in teeth with palatal side abfractions were observed at high frequency in cuspal inclined plane, central fossa, and marginal ridge, and there was a statistical significance $(P<0.05)$. Conclusion: Palatal side abfractions were observed at the highest frequency in maxillary 1 st molars, and in all maxillary posterior teeth where palatal side abfractions were found, the occlusal wears were observed. And the occlusal wears were observed at high frequency in cuspal inclined plane, central fossa and marginal ridge. Such results show that abfraction is associated with occlusal force. (J Dent Rehabil Appl Sci 2019;35(3):153-9)
\end{abstract}

Key words: tooth fractures; occlusal force; occlusal wear; molar; premolar

\section{서론}

비우식성 치경부 병소(NCCLs, non-carious cervical lesions)는 치아우식과는 상관없이 발생하는 치경부에서 의 치아 구조의 상실로 정의된다. ${ }^{1}$ 그리고 이 병소는 굴곡 파절(abfraction), 마모(abrasion), 침식(erosion) 3가지로 분류된다. ${ }^{2}$

비우식성 치경부 병소는 많은 빈도로 구내에서 관찰된 다. Bregstrom과 Eliasson ${ }^{3}$ 에 의하면 90\%에서 관찰된다 고 하였고, Smith 등은 $62.2 \%$ 에서 관찰된다고 하였다. 빈도에 대한 수치는 연구마다 다양하게 나타나지만, 연 령이 증가할수록 비우식성 치경부 병소의 빈도는 증가한

*Correspondence to: Gyeong-Je Lee

Professor, Department of Prosthodontics, College of Dentistry, Chosun University, 309, Pilmun-daero, Dong-gu, Gwangju, 61452, Republic of Korea

Tel: +82-10-4635-1998, Fax: +82-62-232-7776, E-mail: Ikj1998@chosun.ac.kr

Received: August 3, 2019/Last Revision: August 19, 2019/Accepted: August 22, 2019
다는 결과는 여러 연구에서 공통적으로 나타났다. ${ }^{4,5}$

비우식성 치경부 병소에 대한 병소의 치료는 주로 복 합레진 등과 같은 재료로 수복해 주는 방법으로 이루어 지고 있으나, ${ }^{6}$ 치료 후 수복물의 잦은 탈락이 관찰되었 다. ${ }^{7}$ 이는 해당 병소에 대한 명확한 원인이 밝혀지지 않 았기 때문으로 판단된다. 비우식성 치경부 병소의 원인 을 밝히기 위해 많은 노력들이 이루어졌다. 그 결과 교합 력에 의한 치질파절, 마찰에 의한 치질결손, 생화학적 원 인에 의한 치질 결손 등 여러 가지 원인들이 보고되었다. ${ }^{8}$ 그리고 여러 원인 중 교합력에 의해 나타난 치경부 치질 의 결손이 Grippo에 의해 굴곡파절로 정의되어졌다. ${ }^{9}$

교합력과 비우식성 치경부 병소와의 연관성을 찾기 위

Copyright@ 2019 The Korean Academy of Stomatognathic Function and Occlusion. (c) It is identical to Creative Commons Non-Commercial License. 
한 많은 연구들이 이루어졌다. Estafan 등 ${ }^{10}$ 은 비우식성 치경부 병소와 교합면 마모와는 연관성이 없다고 하였 다. Wood 등 ${ }^{11}$ 은 교합조정을 하며 비우식성 치경부 병소 의 진행을 관찰하였고 교합조정은 비우식성 치경부 병 소의 진행을 멈추지 못하며, 교합조정은 추천되지 않는 다고 하였다. 이와는 반대되는 연구 결과들도 보고되었 다. 역학적인 분석을 통해 교합력이 치경부 부근 법랑질 에 하중을 준다는 연구와, ${ }^{12-17}$ 장기간의 임상 관찰을 통해 비우식성 치경부 병소와 교합면 마모의 연관성을 보고한 연구도 있었다. ${ }^{18}$

비우식성 치경부 병소는 구개측 보다 협측에서 더 흔 하게 나타난다. ${ }^{10,19}$ 협측에서는 기계적 마찰이 비우식성 치경부 병소의 발생에 많은 영향을 줄 수 있다., ${ }^{5,20,21}$ 다양 한 원인들이 협측의 비우식성 치경부 병소의 발생에 영향 을 줄 수 있고, 그렇기에 비우식성 치경부 병소의 원인을 한 가지로 판단해서는 안된다. ${ }^{8}$

비우식성 치경부 병소와 교합력 사이의 연관성에 대해 연구를 하기 위해선, 교합력에 더 직접적으로 연관이 있 는 굴곡파절에 한정해서 연구가 이루어질 필요가 있다. 그리고 구개측 굴곡파절에 대한 연구는 칫솔질 같은 기 계적 원인을 배제시킬 수 있다는 점에서 의미가 있다.

본 연구에서는 구개측 굴곡파절이 있는 상악 소구치와 대구치에서 교합면 마모 양상을 분석하여, 교합력과 굴 곡파절의 연관성에 대해 논의해보고자 한다.

\section{연구 재료 및 방법}

2015년부터 2019년까지 조선대학교 치과병원에 내원 한 환자들을 대상으로 조사하였다. 상악 구치에서 1 개 이상의 구개측 굴곡파절을 가지고 있는 21세부터 90세 (평균 57.1세), 총 148명(남성 80명, 여성 68명)을 대상으 로 조사를 진행하였다(Table 1). 구내에서 치아를 직접 관찰, 모형 관찰, 모형 스캔을 통해 제작된 가상 모형을 관찰하는 방법으로 조사를 진행하였다. 조선대학교 치과 병원 임상시험 심사위원회의를 거친 후(CUDHIRB 1901 003) 연구를 진행하였다.

\section{구내 검사, 모형 관찰, CAD (Computer Aided Design)자료 조사}

깊이 $0.5 \mathrm{~mm}$ 이상의 명확한 구개측 굴곡파절을 가지 고 있는 총 308 개의 상악 구치(상악 소구치 121 개, 상악
대구치 187개)를 대상으로 조사를 진행하였다. 침식과 마모를 가지고 있는 치아는 분류에서 제외하였다. 그리 고 구개측 굴곡파절을 가지고 있는 치아의 교합면 마모 양상을 기록하였다. 환자의 나이와 성별도 함께 기록하 였다. 구개측 치경부 관찰이 불가능한 전장관이 수복된 치아와 상실치는 분류에서 제외하였다.

\section{교합면 마모 양상의 분류}

교합력이 가해지는 방향에 따라 교합면의 여러 부위에 마모가 발생한다. ${ }^{22}$ 이와같은 교합면 마모 양상에 대해 분석하기 위해 5 부분으로 교합면을 나누어 마모의 유무 를 기록하였다(Fig. 1). ${ }^{23} 1$ 은 협측 교두정, 2는 협측 교두 내사면, 3 은 중심와 및 변연융선, 4 는 설측 교두 내사면, 5 는 설측 교두정으로 총 5 부분으로 나누었다. 1 과 5 부 위는 교두정을 포함한 마모가 있을 때 기록을 하였다.

Table 1. Participants in this study

\begin{tabular}{ccc}
\hline & Number & Mean age (year) \\
\hline Male & 80 & 58.4 \\
Female & 68 & 55.6 \\
Total & 148 & 57.1 \\
\hline
\end{tabular}

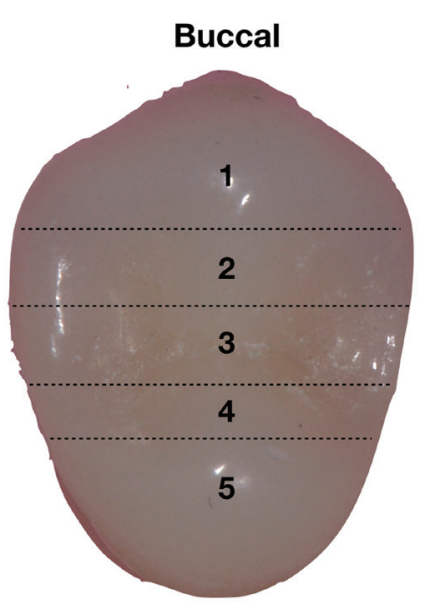

Palatal

Fig. 1. Five segments of occlusal surface depending on buccopalatal axis. Part 1: buccal cusp, Part 2: buccal cuspal inclined plane, Part 3: central fossa \& marginal ridge, Part 4: palatal cuspal inclined plane, Part 5: palatal cusp. 


\section{조사 대상의 분류}

구개측 굴곡파절이 있는 상악 제 1 소구치, 제 2 소구치, 제 1 대구치, 제 2 대구치 각 치아별로 마모 양상을 상기의 분류에 따라 기록하였다. 연령대별 차이, 성별에 따른 차 이를 알아보고자 각 분류별로 자료를 나누어 정리하였다.

\section{통계학적 분석}

SPSS 통계 분석 프로그램(IBM SPSS Statistics 22.0, SPSS INC., Chicago, USA)을 사용하여 통계분석을 진 행하였다. 그룹간의 통계적 유의성을 평가하기 위해 Chisquare test를 시행하였다 $(\alpha=0.05)$.

\section{결과}

상악 소구치와 대구치에서 구개측 굴곡파절이 존재 하는 총 148 명의 환자, 308 개의 치아를 대상으로 조사 를 진행하였다. 구개측 굴곡파절은 제 1 대구치 $(42.5 \%)$ 에 서 가장 많은 빈도로 관찰되었고, 다음으로 제 2 소구치 (19.8\%), 제1소구치(19.5\%), 제2대구치(18\%) 순으로 관 찰되었다(Fig. 2). 또한 구개측 굴곡파절이 있는 모든 치 아에서 최소 하나 이상의 교합면 마모가 관찰되었다.

구개측 굴곡파절이 존재하는 각 치아별로 교합면 마모 양상을 분석하였다. Fig. 1 의 기준대로 나누어 마모 양상 을 기록하였다(Table 2). 상악 제 1 소구치와 상악 제 2 소구 치, 상악 제 1 대구치, 상악 제 2 대구치 모두에서 협측 교두 내사면, 중심와와 변연융선, 설측 교두 내사면에서 마모 면이 많은 빈도로 관찰되었다. 모든 치아에서 협측 교두 의 마모는 다른 부위에 비해 적은 마모가 적은 빈도로 관 찰되었다. 각 치아에서 교합면 마모의 차이는 통계적으 로 유의한 차이를 보였다 $(P<0.05)$.
연령에 따른 교합면 마모 양상의 차이를 Fig. 1 의 기준 으로 분석하였다(Table 3). 29세 이하와 30 - 39세 에서는 구개측 굴곡파절이 존재하는 상악 구치의 수가 각각 13 개, 12 개로 각 부분별 교합면 마모의 수의 차이가 통계적 으로 유의한 차이를 보이지 않았다(20세 이하 $P<0.292$, 30 - 39세 $P$ < 0.724). 40세 이상의 모든 연령대에서 협측 교두 내사면, 중심와와 변연융선, 설측 교두 내사면에서 높은 빈도의 교합면 마모가 나타났으며, 통계적으로 유 의한 차이를 보였다 $(P<0.05)$.

성별에 따른 교합면 마모 양상의 차이도 Fig. 1 의 기준 을 사용해 분석하였다(Table 4). 남성과 여성 모두에서 협 측 교두 내사면, 중심와와 변연융선, 설측 교두 내사면에 서 높은 빈도의 교합면 마모가 나타났고, 통계적으로도 유의한 차이를 보였다 $(P<0.05)$. 또한 여성보다 남성에 서 설측교두에서 교합면 마모가 비교적 높게 나타났다.

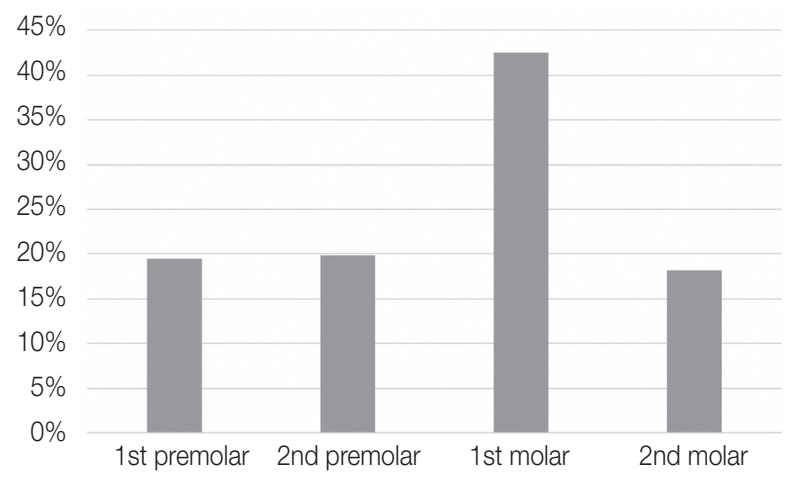

Fig. 2. Distribution of palatal side abfractions in maxillary premolars and molars $(n=308)$.

Table 2. Occlusal wear patterns depending on type of teeth with palatal side abfractions (Parts defined in Fig. 1)

\begin{tabular}{lccccccc}
\hline & Total teeth & Part 1 & Part 2 & Part 3 & Part 4 & Part 5 & $P$ \\
\hline 1st premolar & 60 & $19(31.7 \%)$ & $56(93.3 \%)$ & $52(86.7 \%)$ & $52(86.7 \%)$ & $38(63.3 \%)$ & $<0.000^{\mathrm{a}}$ \\
2nd premolar & 61 & $11(18.0 \%)$ & $58(95.1 \%)$ & $61(100.0 \%)$ & $57(93.4 \%)$ & $47\left(77.0^{\circ} \%\right)$ & $<0.000^{\mathrm{b}}$ \\
1st molar & 131 & $23(17.6 \%)$ & $129(98.5 \%)$ & $130(99.2 \%)$ & $128(97.7 \%)$ & $117(80.5 \%)$ & $<0.000^{\mathrm{c}}$ \\
2nd molar & 56 & $6(10.7 \%)$ & $53(94.6 \%)$ & $55(98.2 \%)$ & $56(100.0 \%)$ & $52\left(92.9^{\circ} \%\right)$ & $<0.000^{\mathrm{d}}$ \\
\hline
\end{tabular}

Chi-square test, $\alpha=0.05$.

${ }^{a} X^{2}: 77.553, d f=4 ;{ }^{b} X^{2}: 157.218, d f=4 ;{ }^{c} X^{2}: 417.395, d f=4 ;{ }^{d} X^{2}: 201.497$, df $=4$. 
Table 3. Occlusal wear patterns in teeth with palatal side abfractions depending on age (Parts defined in Fig. 1)

\begin{tabular}{lccccccc}
\hline & Total teeth & Part 1 & Part 2 & Part 3 & Part 4 & Part 5 & $P$ \\
\hline Below 29 & 13 & $3(23.1 \%)$ & $5(38.5 \%)$ & $8(61.5 \%)$ & $7(53.8 \%)$ & $7(53.8 \%)$ & $<0.292^{\mathrm{a}}$ \\
$30-39$ & 12 & $7(58.3 \%)$ & $10(83.3 \%)$ & $9(75.0 \%)$ & $8(66.7 \%)$ & $8(66.7 \%)$ & $<0.724^{\mathrm{b}}$ \\
$40-49$ & 56 & $15(26.8 \%)$ & $54(96.4 \%)$ & $53(94.6 \%)$ & $53(94.6 \%)$ & $32(57.1 \%)$ & $<0.000^{\mathrm{c}}$ \\
$50-59$ & 100 & $33(33.0 \%)$ & $97(97.0 \%)$ & $98(98.0 \%)$ & $94\left(94.0^{\circ} \%\right)$ & $63(63.0 \%)$ & $<0.000^{\mathrm{d}}$ \\
$60-69$ & 87 & $34(39.1 \%)$ & $86(98.9 \%)$ & $86(98.9 \%)$ & $84(96.6 \%)$ & $62(71.3 \%)$ & $<0.000^{\mathrm{e}}$ \\
Over 70 & 45 & $15(33.3 \%)$ & $44(97.8 \%)$ & $45(100.0 \%)$ & $43(95.6 \%)$ & $32(71.1 \%)$ & $<0.000^{\mathrm{f}}$ \\
\hline
\end{tabular}

Chi-square test, $\alpha=0.05$.

${ }^{\mathrm{a}} \mathrm{X}^{2}: 4.952$, df $=4 ;{ }^{\mathrm{b}} \mathrm{X}^{2}: 2.063$, df $=4 ;{ }^{\mathrm{c}} \mathrm{X}^{2}: 112.400$, df $=4 ;{ }^{\mathrm{d}} \mathrm{X}^{2}: 184.190$, df $=4 ;{ }^{\mathrm{e}} \mathrm{X}^{2}: 153.894$, df $=4 ;{ }^{\mathrm{f}} \mathrm{X}^{2}: 88.918$, df $=4$.

Table 4. Occlusal wear patterns in teeth with palatal side abfractions depending on gender (Parts defined in Fig. 1)

\begin{tabular}{lccccccc}
\hline & Total teeth & Part 1 & Part 2 & Part 3 & Part 4 & Part 5 & $P$ \\
\hline Male & 168 & $40(23.8 \%)$ & $162(96.4 \%)$ & $166(98.8 \%)$ & $163(97.0 \%)$ & $146(86.9 \%)$ & $<0.000^{\mathrm{a}}$ \\
Female & 140 & $19(13.6 \%)$ & $134(95.7 \%)$ & $132(94.3 \%)$ & $130(92.9 \%)$ & $108(77.1 \%)$ & $<0.000^{\mathrm{b}}$ \\
\hline
\end{tabular}

Chi-square test, $\alpha=0.05$.

${ }^{a} X^{2}: 442.231, \mathrm{df}=4 ;{ }^{b} X^{2}: 362.934, \mathrm{df}=4$.

\section{고찰}

비우식성 치경부 병소의 증상은 굴곡파절과 마모, 침식 과 같이 다양하게 나타난다. ${ }^{2}$ 그리고 비우식성 치경부 병 소에는 다양한 원인이 존재하며 여러 원인들이 복합적으 로 작용한다. ${ }^{8}$ 증상과 원인이 다양하기에, 비우식성 치경 부 병소에 대해 연구를 하기 위해서는 연구하고자 하는 증상을 특정하여, 주된 원인에 대해 연구할 필요가 있다.

굴곡파절은 비우식성 치경부 병소의 한 종류로 Grippo 에 의해 교합력에 의한 병적인 치질의 상실로 정의되어졌 다. ${ }^{9}$ 이후 교합력과 굴곡파절의 연관성에 대해 연구가 진 행되었고, 교합력과 굴곡파절에 대해 연관성이 있음이 많은 연구들에 의해 보고되었다. ${ }^{12-18,24}$ 본 연구에서는 상 악 소구치와 대구치에서 나타난 명확한 구개측 굴곡파절 을 대상으로 조사를 시행하였다. 상악 제1대구치에서 가 장 많은 빈도로 구개측 굴곡파절이 관찰되었고, 구개측 굴곡파절이 존재하는 모든 치아에서 최소 하나 이상의 교합면 마모가 관찰되었다. 교합력과 교합면 마모에는 연관성이 있으며, ${ }^{25}$ 제 1 대구치에서 가장 많은 빈도로 구 개측 굴곡파절이 관찰되었다는 점은 굴곡파절과 교합력 사이에 연관성이 있음을 의미한다.
본 연구에서는 구개측 굴곡파절이 있는 치아에서 교합 면 마모 양상을 분석하였다. 상악 소구치와 대구치 모두 에서 협측과 구개측 교두(Part 1 \& 5), 협측과 구개측 교 두 내사면(Part $2 \& 4$ ), 중심와와 변연융선(Part 3) 총 5가 지 부위로 나누어 마모면을 기록하였고, 구분은 Kullmer 등 $^{22}$ 의 연구와 Brandini 등 ${ }^{23}$ 의 연구를 참고하였다(Fig. 1).

각 치아별로 교합면 마모를 살펴봤을 때(Table 2), 모 든 치아에서 공통적으로 나타난 부분은 협측 교두 내사 면, 중심와와 변연융선, 구개측 교두 내사면에서 높은 빈 도로 마모면이 관찰되었다는 점이다. 또한 모든 치아에 서 비기능교두인 협측교두의 마모보다 기능교두인 구개 측 교두에서의 마모가 많은 빈도로 관찰되었으며, 전방 에서 후방 치아로 갈수록 구개측 교두의 마모가 더 많은 빈도로 관찰되었다. 이와 같은 결과를 바탕으로 구개측 굴곡파절이 존재하는 치아에서 교두 내사면과 중심와와 변연융선에서 대합치에 의해 교합력이 가해졌으며, 해당 부위에 가해진 교합력과 굴곡파절이 연관성이 있다고 사 료된다. 후방 치아로 갈수록 기능교두인 구개측 교두 마 모가 증가한 부분은 더 많은 교합력이 소구치보다 대구 치에서 가해졌음을 의미하며, 이와 같은 양상이 구개측 
굴곡파절을 가진 치아에서 나타난 부분 또한 교합력과 굴곡파절과 연관성이 있음을 의미한다.

연령에 따른 교합면 마모의 결과에서는(Table 3), 39세 이하에서는 구개측 굴곡파절을 가진 치아수가 적었으며, 다양한 마모 양상이 관찰되었으나 해당 차이는 통계적으 로 유의성을 보이지 않았다. 비우식성 치경부 병소는 연 령이 증가할수록 발생 빈도도 증가한다. ${ }^{4,5,26}$ 낮은 빈도로 관찰되는 젊은 환자의 비우식성 치경부 병소에 대한 연 구로는 원인을 파악하기에 어려움이 있으며, 이 때문에 젊은 학생을 대상으로 한 비우식성 치경부 병소와 교합 면 마모의 연관성에 대한 연구에서 두 가지 사항이 연관 성이 없다고 한 부분은 이상하지 않다. ${ }^{10} 40$ 세 이상부터 는 구개측 굴곡파절이 많은 치아에서 관찰되었으며, 교 합면 마모가 교두 내사면과 중심와 및 변연융선에서 많 은 빈도로 관찰되었다. 이는 구개측 굴곡파절의 원인으 로 교두 내사면과 중심와 및 변연융선에서의 교합 접촉 을 고려함이 바람직하다.

성별에 따른 교합면 마모의 결과는(Table 4), 남녀 모 두에서 교두 내사면과 중심와 및 변연융선에서 높은 빈 도로 마모면이 관찰되었다. 이와 같은 결과는 교두 내사 면과 중심와 및 변연융선에서의 교합 접촉이 구개측 굴 곡파절과 연관이 있다는 것을 의미한다. 또한 구개측 교 두 마모가 여성보다 남성에서 더 많은 빈도로 관찰이 되 었는데, 이는 성별간의 교합력 차이 때문에 발생한 차이 로 사료된다.

본 연구에서는 상악 소구치와 대구치에서 구개측 굴곡 파절이 있는 치아를 대상으로 교합면 마모 양상을 분석 하여 두 가지에 대한 연관성을 밝혀보고자 하였다. 구개 측 굴곡파절이 있는 모든 치아에서 최소 하나 이상의 교 합면 마모가 관찰되었고, 교합면 마모는 교두 내사면과 중심와 및 변연융선에서 높은 빈도로 관찰되었다. 이와 같은 결과는 굴곡파절의 주된 원인은 교합력이며, 주로 교두 내사면과 중심와 및 변연융선에 가해지는 교합력이 구개측 굴곡파절과 연관성이 있음을 보여준다.

\section{결론}

상악의 소구치와 대구치에서 구개측 굴곡파절과 교합면 의 마모 양상을 분석한 결과, 다음과 같은 결과를 얻었다.

상악 제 1 대구치에서 가장 많은 빈도로 구개측 굴곡파 절이 관찰되었으며, 구개측 굴곡파절이 있는 모든 치아 에서 교합면 마모가 관찰되었다.
구개측 굴곡파절이 존재하는 치아에서 교합면 마모는 교두 내사면과 중심와 및 변연융선에서 많은 빈도로 관 찰되었다.

교두 내사면과 중심와 및 변연융선에 가해지는 교합력 이 구개측 굴곡파절과 연관이 있으며, 구개측 굴곡파절 의 주된 원인으로 교합력을 고려해야한다.

\section{Acknowledgements}

이 논문은 2017년도 조선대학교 치과병원 학술연구비 의 지원을 받아 연구되었음

\section{ORCID}

Joo-Hun Song https://orcid.org/0000-0003-4229-6148

Hee-Jung Kim https://orcid.org/0000-0002-2015-1530

Gyeong-Je Lee https://orcid.org/0000-0002-3545-2280

\section{References}

1. Aw TC, Lepe X, Johnson GH, Mancl L. Characteristics of noncarious cervical lesions: a clinical investigation. J Am Dent Assoc 2002;133:725-33.

2. Bader JD, McClure F, Scurria MS, Shugars DA, Heymann HO. Case-control study of non-carious cervical lesions. Community Dent Oral Epidemiol 1996;24:286-91.

3. Bergström J, Eliasson S. Cervical abrasion in relation to toothbrushing and periodontal health. Scand J Dent Res 1988;96:405-11.

4. Smith WA, Marchan S, Rafeek RN. The prevalence and severity of non-carious cervical lesions in a group of patients attending a university hospital in Trinidad. J Oral Rehabil 2008;35:128-34.

5. Levitch LC, Bader JD, Shugars DA, Heymann HO. Non-carious cervical lesions. J Dent 1994;22:195207.

6. Nascimento MM, Gordan VV, Qvist V, Bader JD, Rindal DB, Williams OD, Gewartowski D, Fellows JL, Litaker MS, Gilbert GH; Dental Practice-Based Research Network Collaborative Group. Restoration of noncarious tooth defects by dentists in The Dental Practice-Based Research Network. J Am Dent Assoc 2011;142:1368-75. 
7. Ichim IP, Schmidlin PR, Li Q, Kieser JA, Swain MV. Restoration of non-carious cervical lesions: Part II. Restorative material selection to minimise fracture. Dent Mater 2007;23:1562-9.

8. Grippo JO, Simring M, Coleman TA. Abfraction, abrasion, biocorrosion, and the enigma of noncarious cervical lesions: a 20-year perspective. J Esthet Restor Dent 2012;24:10-23.

9. Grippo JO. Abfractions: A New Classification of Hard Tissue Lesions of Teeth. J Esthet Dent 1991;3:14-9.

10. Estafan A, Furnari PC, Goldstein G, Hittelman EL. In vivo correlation of noncarious cervical lesions and occlusal wear. J Prosthet Dent 2005;93:221-6.

11. Wood ID, Kassir AS, Brunton PA. Effect of lateral excursive movements on the progression of abfraction lesions. Oper Dent 2009;34:273-9.

12. Goel VK, Khera SC, Ralston JL, Chang KH. Stresses at the dentinoenamel junction of human teeth-a finite element investigation. J Prosthet Dent 1991;66:451-9.

13. Chen KK, Miyake K, Terashita M. Cervical strains induced by occlusal loading. J Dent Res 1999;78:474.

14. Nohl FS, McCabe JF, Walls AWG. The effect of load angle on strains induced in maxillary premolars in vitro. J Dent Res 1999;78:1059.

15. Dejak B, Mlotkowski A, Romanowicz M. Finite element analysis of mechanism of cervical lesion formation in simulated molars during mastication and parafunction. J Prosthet Dent 2005;94:520-9.

16. Lee $\mathrm{HE}$, Lin $\mathrm{CL}$, Wang $\mathrm{CH}$, Cheng $\mathrm{CH}$, Chang $\mathrm{CH}$. Stresses at the cervical lesion of maxillary premolar-a finite element investigation. J Dent 2002;30:283-90.

17. Rees JS. The biomechanics of abfraction. Proc Inst Mech Eng H 2006;220:69-80.
18. Pintado MR, DeLong R, Ko CC, Sakaguchi RL, Douglas WH. Correlation of noncarious cervical lesion size and occlusal wear in a single adult over a 14-year time span. J Prosthet Dent 2000;84:436-43.

19. Rees JS, Hammadeh M, Jagger DC. Abfraction lesion formation in maxillary incisors, canines and premolars: a finite element study. Eur J Oral Sci 2003;111:149-54.

20. Miller WD. Experiments and observations on the wasting of tooth tissue variously designated as erosion, abrasion, chemical abrasion, denudation, etc III. Dent Cosm 1907;49:225-47.

21. Radentz WH, Barnes GP, Cutright DE. A survey of factors possibly associated with cervical abrasion of tooth surfaces. J Periodontol 1976;47:14854.

22. Kullmer O, Benazzi S, Fiorenza L, Schulz D, Bacso S, Winzen O. Technical note: occlusal fingerprint analysis: quantification of tooth wear pattern. Am J Phys Anthropol 2009;139:600-5.

23. Brandini DA, Trevisan CL, Panzarini SR, Pedrini D. Clinical evaluation of the association between noncarious cervical lesions and occlusal forces. J Prosthet Dent 2012;108:298-303.

24. Sawlani K, Lawson NC, Burgess JO, Lemons JE, Kinderknecht KE, Givan DA, Ramp L. Factors influencing the progression of noncarious cervical lesions: A 5-year prospective clinical evaluation. J Prosthet Dent 2016;115:571-7.

25. Benazzi S, Kullmer O, Grosse IR, Weber GW. Using occlusal wear information and finite element analysis to investigate stress distributions in human molars. J Anat 2011;219:259-72.

26. Harvey WL, Hatch RA, Osborne JW. Computerized occlusal analysis: an evaluation of the sensors. J Prosthet Dent 1991;65:89-92. 


\section{구개측 굴곡파절이 있는 상악 구치의 교합면 마모 양상에 대한 연구}

\section{송주헌, 김희중, 이경제*}

조선대학교 치과대학 치과보철학교실

목적: 구개측 굴곡파절이 있는 상악 구치의 교합면 마모 양상을 분석하여, 교합력과 굴곡파절의 연관성에 대해 연구해보 고자 한다.

연구 재료 및 방법: 상악 구치에서 구개측 굴곡파절을 가지고 있는 148 명의 환자, 총 308 개의 치아를 대상으로 조사를 진 행하였다. 구개측 굴곡파절을 가지고 있는 상악 소구치와 대구치의 교합면 마모를 분류 및 기록하였다. 치아별, 연령별, 성별에 따라 분류를 진행하였고, 그룹간의 통계적 유의성을 평가하기 위해 Chi-square test를 시행하였다 $(\alpha=0.05)$.

결과: 상악 구치에서 구개측 굴곡파절은 제1대구치에서 가장 높은 빈도로 관찰되었고, 구개측 굴곡파절이 있는 모든 치 아에서 하나 이상의 교합면 마모가 관찰되었다. 치아별, 연령별, 성별 모두에서 구개측 굴곡파절이 있는 치아의 교합면 마모는 교두 내사면과 중심와 및 변연융선에서 높은 빈도로 관찰되었으며 통계적으로 유의성이 있었다 $(P<0.05)$.

결론: 구개측 굴곡파절은 상악 제1대구치에서 가장 많은 빈도로 관찰되었고, 구개측 굴곡파절이 관찰된 상악 구치 모두 에서 교합면 마모가 관찰되었다. 그리고 교합면 마모는 교두 내사면과 중심와 및 변연융선에서 많은 빈도로 관찰되었다.

이와 같은 결과는 굴곡파절이 교합력과 연관이 있음을 보여준다.

(구강회복응용과학지 2019;35(3):153-9)

주요어: 치아파절; 교합력; 교합면 마모; 대구치; 소구치

*교신저자: 이경제

(61452) 광주광역시 동구 필문대로 309 조선대학교 치과대학 치과보철학교실

Tel: 010-4635-1998 | Fax: 062-232-7776 | E-mail: Ikj1998@chosun. ac. kr

접수일: 2019년 8월 3일 | 수정일: 2019년 8월 19일 | 채택일: 2019년 8월 22일 